\title{
Peter Pan Chronology
}

May 9, 1860 James M. Barrie is born in Kirriemuir, Scotland.

1902 J. M. Barrie publishes his first Peter Pan story, "The Little White Bird, or Adventures in Kensington Gardens."

1904 Peter Pan premieres at the Duke of York Theatre in London, with Nina Boucicault as Peter Pan.

1905 Peter Pan opens in New York City, with Maude Adams in the lead role.

1906 J. M. Barrie publishes Peter Pan in Kensington Gardens, which tells the story of Peter's escape from the nursery and his adventures among the birds and fairies.

1911 J. M. Barrie publishes Peter and Wendy, which develops the story of the Darling children and their adventures with Peter Pan in Neverland.

1912 Sir George Frampton's statue of Peter Pan erected in Kensington Gardens.

1915 The sinking of the Lusitania, on which Peter Pan producer Charles Frohman drowned after paraphrasing the line, "To die will be an awfully big adventure."

1929 J. M. Barrie gives the copyright for Peter Pan to Great Ormond Street Children's Hospital.

June 3, 1937 J. M. Barrie dies; the bequest of the Peter Pan copyright is reaffirmed.

1953 Disney's animated version of Peter Pan hits American silver screens.

1954 Staging of Broadway musical of Peter Pan premieres with Mary Martin in the starring role. NBC airs the first televised Peter Pan based on the Martin performance. It was shown 
three more times on television before 1960, when it was color videotaped and shown in 1963, 1966, and 1973.

1974 Cathy Rigby assumes the role of Peter Pan on stage and on television.

1979 Sandy Duncan takes the role of Peter Pan in the Broadway revival.

1991 Steven Spielberg releases the film Hook.

2000 Diarmuid Bryan O'Connor's new statue of Peter Pan is unveiled outside Great Ormond Street Children's Hospital.

2001 Director P. J. Hogan releases Peter Pan.

2002 Walt Disney Studios releases its animated sequel, Return to Neverland.

2004 Director Marc Forster releases the film Finding Neverland.

2006 Geraldine McCaughrean publishes an authorized sequel, Peter Pan in Scarlet. 
Second Star to the Right 
A friend characterized it as a "Peter Pan view," and now I can't see it any other way. I lie awake thinking of someone with a hook for a hand, and then, inevitably, of youth, and whether I have wasted it.

—David Sedaris, When You Are Engulfed in Flames, 2008 